\title{
非拡散性水素吸蔵による伸線強加工高強度鋼の 疲労強度低下と水素トラップサイトの活性化エネルギーの関係*
}

\author{
中谷 正 憲*1, 箕島 弘二*1, 㠃原 雅 之*2
}

\section{Relationship Between the Activation Energy of Hydrogen Trap Site and a Decrease in Fatigue Strength by Absorption of Irreversible Hydrogen in Cold-Drawn High Strength Steels}

\author{
Masanori NAKATANI ${ }^{* 3}$, Kohji MINOSHIMA and Masayuki SAKIHARA \\ ${ }^{* 3}$ Department of Mechanical Engineering, Osaka University, \\ 2-1 Yamadaoka, Suita-shi, Osaka, 565-0871 Japan
}

\begin{abstract}
Fatigue tests have been conducted to investigate the influence of irreversible hydrogen and its activation energy for hydrogen desorption from trap site on the fatigue strength for cold-drawn high strength steels with different activation energy, but having the same chemical composition. Specimens were cathodically hydrogen charged, and internal hydrogen states were changed as follows : (a) non-charged sample and (b) the one that contained only irreversible hydrogen. Since the fatigue crack was initiated at internal inclusion or microstructural inhomogeneity, the fatigue strength was discussed based on the stress intensity factor calculated from stress and defect size. In the case of the sample with higher activation energy, $71.4 \mathrm{~kJ} / \mathrm{mol}$, irreversible hydrogen had no influence on the fatigue strength. In this case, the fracture surfaces of the sample with and without irreversible hydrogen were the same. However, for the sample with lower activation energy, $60.3 \mathrm{~kJ} /$ mol, the fatigue strength of the specimen having only irreversible hydrogen decreased compared with non-charged specimens. The fracture surface of the sample with irreversible hydrogen was brittle compared with that of non-charged sample. This indicates that the influence of irreversible hydrogen on the fatigue strength tends to become small with increasing activation energy for irreversible hydrogen desorption.
\end{abstract}

Key Words : High Strength Steel, Hydrogen Embrittlement, Fatigue, Irreversible Hydrogen, Inclusion, Activation Energy, Thermal Desorption Spectrometry (TDS), Cold Drawing

\section{1. 粕言}

高強度鋼は, 使用環境中からの水素の侵入により水 素ぜい化を生じることが知られており，多くの研究者 によって, 水素ぜい化機構(1) (4)や発生・伝ぱに及ぼす 材料・環境因子に関して研究が行われてきた. 近年, 昇温水素分析技術の向上により, 鋼中に吸蔵された水 素は拡散性水素と非拡散性水素の 2 種類のエネルギー 状態で存在し, 静的荷重下においては拡散性水素のみ が水素ぜい化に寄与し，非拡散性水素はほとんど影響 しないことが報告されている(5) (6). したがって，限界 拡散性水素量をもとに, 水素ぜい化環境下における構 造材の信頼性評価が行われている(7)。 また, 組織制御 を用いて，非拡散性水素のトラップサイトとなり得る $\mathrm{TiC}^{(8)} \mathrm{VC}^{(9)}$ などの微細遷移金属炭化物を分散させ,

\footnotetext{
* 原稿受付 2007 年 8 月 20 日.

*1 正員, 大阪大学大学院工学研究科 (宓565-0871 吹田市山田 丘 2-1).

*2 大阪大学大学院工学研究科.

E-mail : k-minoshima@mech.eng.osaka-u.ac.jp
}

破壊が生じているき裂先端への水素の拡散を防ぐこと を指針として，耐水素ぜい化特性に優れた材料の研 究・開発が進められている.

しかし, 筆者ら ${ }^{(10)}$ の研究により, 伸線強加工高強度 鋼において，非拡散性水素のみを吸蔵した状態であっ ても，水素を吸蔵していない受入材に比べて疲労強度 が低下し，その破面はぜい性的な様相を呈することが 明らかになった。したがって, 非拡散性水素吸蔵によ る疲労強度低下は, 前述の耐水素ぜい化特性に優れた 材料の創製指針を根底から覆す問題であり, 機械・構 造物の信頼性を確保する上で, 非拡散性水素吸蔵によ る疲労強度低下の機構および影響因子の解明は急務で ある.

本研究では, 非拡散性水素吸蔵による疲労強度低下 の機構解明を目的として, 非拡散性水素トラップサイ 卜の活性化エネルギ一に着目し，それらの特性と非拡 散性水素吸蔵による疲労強度低下との関連について検 討した. 


\section{2. 供試材および実験方法}

$2 \cdot 1$ 供試材 供試材は, 以下の式(1)で定義する 伸線加工減面率 64\%，90\%（以下 $64 \%$ 材および $90 \%$ 材 と称する）の泠間伸線加工を施した伸線強加工高強度 鋼である.

$$
\varphi=\left(A_{0}-A_{1}\right) / A_{0} \times 100
$$

ここで, $A_{0}$ および $A_{1}$ はそれぞれ加工前と加工後の断面 積である. 64\%材および 90\%材の直径はそれぞれ 3.3 $\mathrm{mm}, 1.72 \mathrm{~mm}$ である. 化学成分および機械的性質をそ れぞれ表 1,2 に示寸. 両者ともに引抜方向に組織が引 き伸ばされた強加工パーライト組織であり，伸線加工 により組織異方性を有する．疲労試験にあたっては, 長さ $170 \mathrm{~mm}$ の試験片中央部に曲率半径 $5 \mathrm{~mm}$ の環状切 欠きを研削加工により設けた後，表面加工層を取り除 くために，64\%材および $90 \%$ 材の最小断面部直径がそ れぞれ $1.6 \mathrm{~mm}, 0.9 \mathrm{~mm}$ となるように電解研磨により最 終仕上げを施した，なお，応力集中係数はいずれも約 1.05 である.

$2 \cdot 2$ 実験方法 応力比 $R=0$, 繰返し速度 $30 \mathrm{~Hz}$ の正弦波波形を用いた疲労試験を実施した。試験には 電気・油圧サーボ疲労試験機を用いた，疲労強度特性 に及ぼす非拡散性水素の影響を調べるために，（1）水 素チャージを行っていない未チャージ材，（2）試験片 内の水素吸蔵量が飽和する (64\%材: 9 時間，90\%材: 6 時間) まで予備水素チャージを施した後, 乾燥空気（露

Table 1 Chemical composition (mass \%).

\begin{tabular}{|c|c|c|c|c|c|}
\hline $\mathrm{C}$ & $\mathrm{Si}$ & $\mathrm{Mn}$ & $\mathrm{P}$ & $\mathrm{S}$ & $\mathrm{Cu}$ \\
\hline 0.96 & 0.19 & 0.69 & 0.017 & 0.060 & 0.21 \\
\hline $\mathrm{Ni}$ & $\mathrm{Cr}$ & $\mathrm{Al}$ & $\mathrm{N}$ & $\mathrm{O}$ & $\mathrm{Fe}$ \\
\hline 0.07 & 0.2 & 0.011 & 0.0117 & 0.0013 & bal. \\
\hline
\end{tabular}

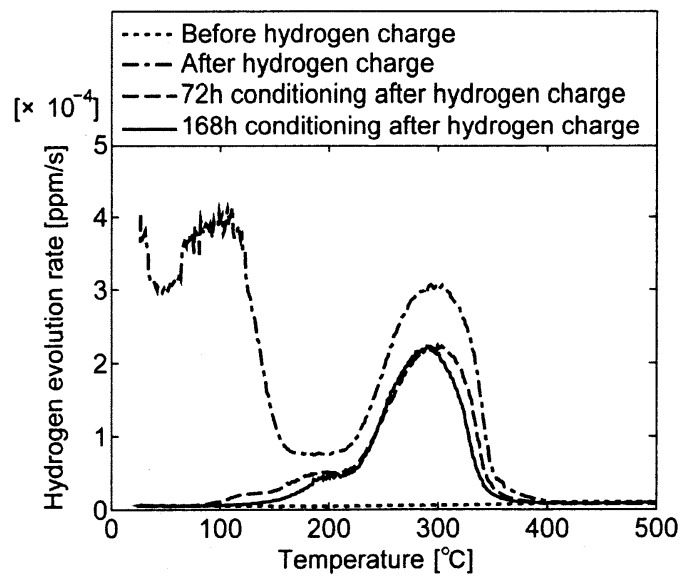

(a) Reduction in area by drawing: $64 \%$
点: $\left.-67^{\circ} \mathrm{C}\right)$ 中に 72 時間放置して拡散性水素を放出させ, 非拡散性水素のみを吸蔵させた非拡散性水素吸蔵材の 2 種類の水素吸蔵状態の試料を用いた。 なお，試験環 境からの水素の侵入を防ぐため, 試験は乾燥空気（露 点: $-67^{\circ} \mathrm{C}$ ) 中で実施した. 試験片はいずれの場合も試 験片最小断面部で破断した，疲労試験後には，すべて の試験片に対して電界放射型走査電子顕微鏡による破 面観察を行った.

水素チャージはカソード電解法により，酶酸・酶酸 ナトリウム緩衝容液 $(0.2 \mathrm{~mol} / \mathrm{L} \mathrm{CH} 3 \mathrm{COOH}+0.17 \mathrm{~mol} / \mathrm{L}$ $\left.\mathrm{CH}_{3} \mathrm{COONa}, \mathrm{pH}=4.8\right)$ 中で, 試料に対して $500 \mathrm{~A} / \mathrm{m}^{2}$ の 電流を印加することで行った，また，水素チャージを 施した試料の水素吸蔵特性を把握するために昇温水素 分析を行った．測定には検出部に四重極質量分析計を もつ昇温脱離ガス分析装置 (Thermal Desorption Spectrometry: TDS) を用いた. 加熱は $100^{\circ} \mathrm{C} / \mathrm{h}$ の定速昇 温とし，測定温度範囲は室温 $500^{\circ} \mathrm{C}$ とした.

\section{3. 実験結果および考察}

$3 \cdot 1$ 水素吸藏特性＼cjkstart水素チャージを施した $64 \%$ 材および $90 \%$ 材に対して昇温水素分析を行い，水素吸 蔵特性を調べた. $64 \%$ 材および $90 \%$ 材の水素放出曲線 をそれぞれ図 1(a),(b)に示す. 両供試材の水素放出挙動 について，以下のような共通点が見られる. 図中の点 線で示すように受入材のままでは，水素放出はほとん

Table 2 Mechanical properties.

\begin{tabular}{|c|c|c|c|}
\hline $\begin{array}{c}\text { Reduction } \\
\text { in area by } \\
\text { drawing [\%] }\end{array}$ & $\begin{array}{c}\text { Tensile } \\
\text { strength } \\
{[\mathrm{MPa}]}\end{array}$ & $\begin{array}{c}0.2 \% \text { offset } \\
\text { yield strength } \\
{[\mathrm{MPa}]}\end{array}$ & $\begin{array}{c}\text { Elongation } \\
{[\%]}\end{array}$ \\
\hline 64 & 1728 & 1400 & 3.6 \\
\hline 90 & 2395 & 2000 & 2.5 \\
\hline
\end{tabular}

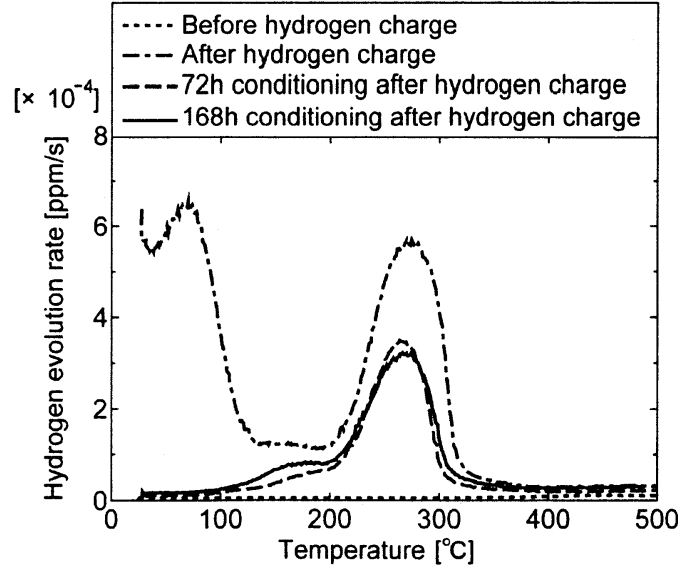

(b) Reduction in area by drawing: $90 \%$

Fig. 1 Hydrogen evolution rate as a function of temperature measured by TDS. 
ど見られないが，水素チャージを施すと，一点鎖線で 示すように, 2 つの水素放出ピークが明瞭に現れてい る. 一方, 水素チャージ後 72 時間乾燥空気中に放置す ると，破線で示すように水素チャージ直後に低温側に 存在した水素放出ピークは消滅した．高温側の水素放 出ピークは水素チャージ直後から時間経過によりわず かに減少するものの, 168 時間乾燥空気中に放置した 結果を実線で示すように, 72 時間経過以降は水素放出 ピークの減少は見られない. 以上から, 低温側の水素 放出ピークを拡散性水素, 高温側の水素放出ピークを 非拡散性水素の放出と対応づけることができる.

水素チャージ直後の水素放出曲線において $150^{\circ} \mathrm{C}$ 以 下で放出される水素を拡散性水素, 水素チャージから 72 時間経過後も残存する水素を非拡散性水素と仮定 して吸蔵量を計算したところ，64\%材では拡散性水素 が $1.68 \mathrm{ppm}$, 非拡散性水素が $0.84 \mathrm{ppm}$ であるのに対し て，90\%材ではそれぞれ $3.41 \mathrm{ppm}, 1.21 \mathrm{ppm}$ であった. 伸線加工減面率の増加に伴って, 拡散性水素, 非拡散 性水素ともに吸藏量は増加する傾向にあり，伸線加工 によりトラップサイトが増加したことを意味している。

つぎに，水素のトラップサイトの活性化エネルギー を調べるため, 昇温水素分析において昇温速度 $\alpha$ を 50 , $100,200 \mathrm{~K} / \mathrm{h}$ と変化させて水素放出特性を調べた. これ らの水素放出ピーク温度の昇温速度依存性から，(2)式 で示す Choo-Lee の式(11)より水素トラップサイトの活 性化エネルギーを算出することができる.

$$
\frac{\partial \ln \left(\alpha / T_{\mathrm{c}}{ }^{2}\right)}{\partial\left(1 / T_{\mathrm{c}}\right)}=-\frac{E_{\mathrm{a}}}{R}
$$

ここで， $\alpha$ : 昇温速度 $[\mathrm{K} / \mathrm{h}] ， E_{\mathrm{a}}$ : 活性化エネルギ 一 $[\mathrm{kJ} / \mathrm{mol}], T_{\mathrm{c}}$ : 水素放出ピーク温度 $[\mathrm{K}], R$ : 気体 定数である. $64 \%$ および $90 \%$ 材における $\ln \left(\alpha / T_{\mathrm{c}}^{2}\right)$ と $1 / T_{\mathrm{c}}$ のアレニウスプロットをそれぞれ図 2(a), (b)に示す．また，このアレニウスプロットの傾き から算出した $64 \%$ 材および $90 \%$ 材の活性化エネル ギーを表 3 に示す．拡散性水素のトラップサイト の活性化エネルギーに変化はほとんど見られない. 一方, 非拡散性水素についてみると，90\%材の活 性化エネルギーは $64 \%$ 材のそれに比べて $11 \mathrm{~kJ} / \mathrm{mol}$ 程度上昇しており，伸線加工に伴ってトラップサ イトが安定化していると言える. 転位における水

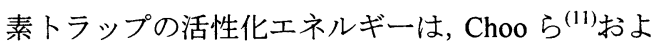
び高井ら ${ }^{(12)}$ がそれぞれ $26.8,28.1 \mathrm{~kJ} / \mathrm{mol}$ と報告し ている. 本研究で得られた拡散性水素の活性化工 ネルギーの值もこれらの值と近いことから, 本供 試材における拡散性水素のトラップサイトは転位 であると考えられる. また, 伸線加工度の増加に
伴って，材料内部の転位密度は増加すると考えら れるが，活性化エネルギーの值に大きな変化が見 られないことから，転位をトラップサイトとした 場合の活性化エネルギーは伸線加工の減面率が 64\%と 90\%の間では, 減面率には依存しないとい える.

一方, 高温側の水素放出ピークに関して, 高井 ら ${ }^{(13)}$ は, 伸線加工を受けたフェライトルメンタイ 卜界面であると報告している，非拡散性水素の卜 ラップサイトであるフェライトルメンタイト界 面と伸線加工の関係について, Makii ら ${ }^{(14)}$ はパー

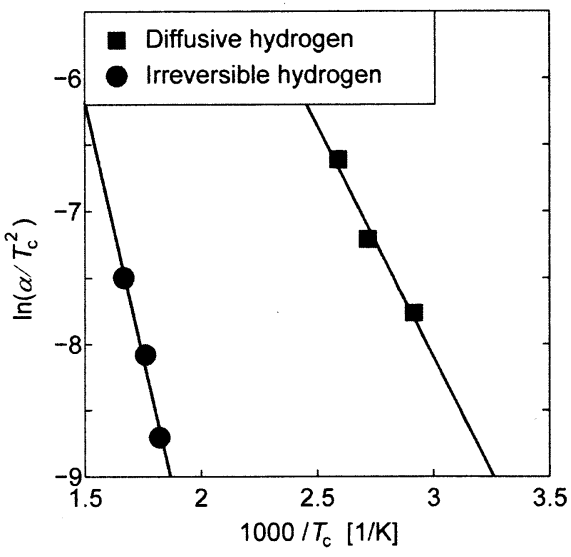

(a) Reduction in area by drawing: $64 \%$

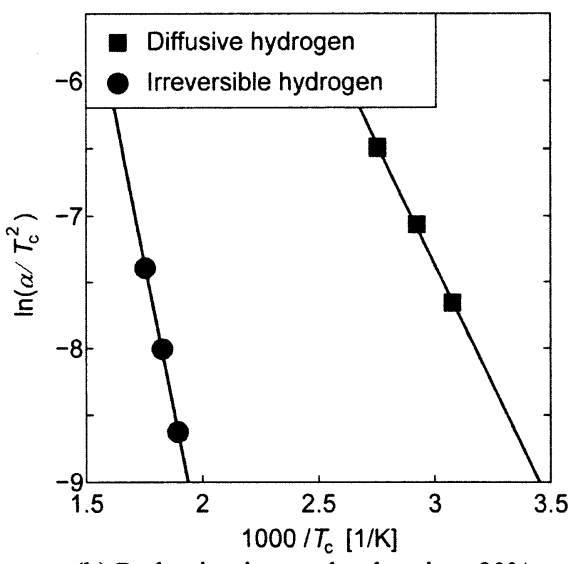

(b) Reduction in area by drawing: $90 \%$

Fig. 2 Relationship between $\ln \left(\alpha / T_{\mathrm{c}}^{2}\right)$ and $1 / T_{\mathrm{c}}$.

Table 3 Activation energy measured by TDS.

\begin{tabular}{|c|c|c|}
\hline Reduction in area by & \multicolumn{3}{|c|}{ Activation energy [kJ/mol] } \\
\cline { 2 - 3 } cold-drawing [\%] & $\begin{array}{c}\text { Diffusive } \\
\text { hydrogen }\end{array}$ & $\begin{array}{c}\text { Irreversible } \\
\text { hydorgen }\end{array}$ \\
\hline 64 & 28.7 & 60.3 \\
\hline 90 & 29.4 & 71.4 \\
\hline
\end{tabular}


ライト鋼線から電解抽出したセメンタイトを電子 顕微鏡で観察し，セメンタイトがナノスケールの 微細組織を有していることを示しており, 非拡散 性水素のトラップと何らかの関係があると考えら れるが，詳細については不明である。

\section{$3 \cdot 2$ 疲労強度特性 $64 \%$ 材および $90 \%$ 材の} $S-N$ 線図を図 3 に示す．絽返し数が $10^{7}$ cycles を超 えても破断しなかった試験結果には右矢印を付し ている。.また， $10^{7}$ cycles 負荷しても破断しなかっ た試験片については，引き続き応力を増加させて 疲労試験を実施した. 図中のアルファベット $(\mathrm{a}, \mathrm{b}$, $\mathrm{c}, \cdots)$ は，この試験における同一の試験片であるこ とを示している．64\%材と $90 \%$ 材を比べると，伸 線加工量の増加により, 疲労強度が向上している ことがわかる。しかしながら，疲労寿命のばらつ きが大きく, $S-N$ 曲線から非拡散性水素吸藏によ

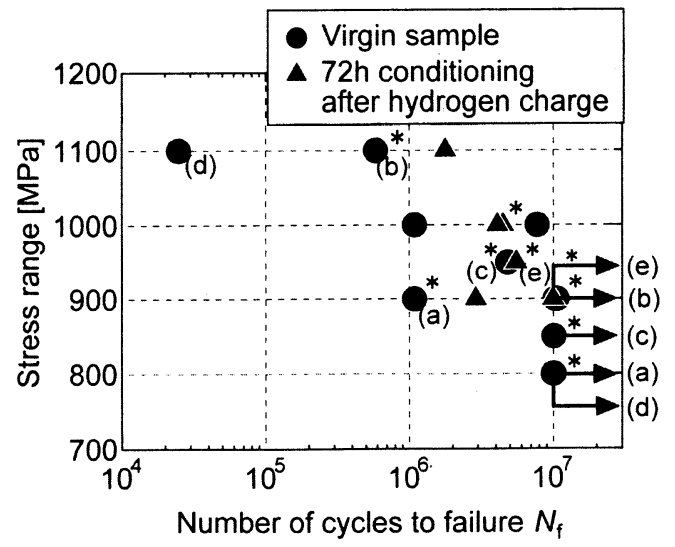

(a) Reduction in area by drawing: $64 \%$
る疲労強度低下の有無を判断することは困難であ る. 本研究における疲労破壊の起点は, $90 \%$ 材で は材料内部の介在物, $64 \%$ 材では介在物または図 3(a)で*印を付して示す組織割れ ${ }^{(15),(16)}$ であり，それ らの欠陥寸法のばらつきが疲労寿命のばらつきの 原因になったと考えられる，そこで，欠陥をき裂 とみなし, 村上の式(17)を用いて, 久陥寸法を考慮 に入れた応力拡大係数により疲労寿命を評価した.

図 4 に $64 \%$ 材および $90 \%$ 材における破壊起点と なった初期欠陥に対する応力拡大係数範囲 $\Delta K_{\text {ini }}$ と 破断寿命 $N_{\mathrm{f}}$ の関係を示す. 破壊起点が組織割れで あるものには*印を付して示している. 64\%材にお いては, 介在物起点と組織割れ起点の 2 種類が観 察されたが, 未チャージ材の $\Delta K_{\mathrm{ini}}-N_{\mathrm{f}}$ 関係は起点の 種類によらず図中の破線でほぼ近似されること， 破面様相にも違いが見られなかったことからも，

Fig. 3 Influence of irreversible hydrogen on $S-N$ curves.

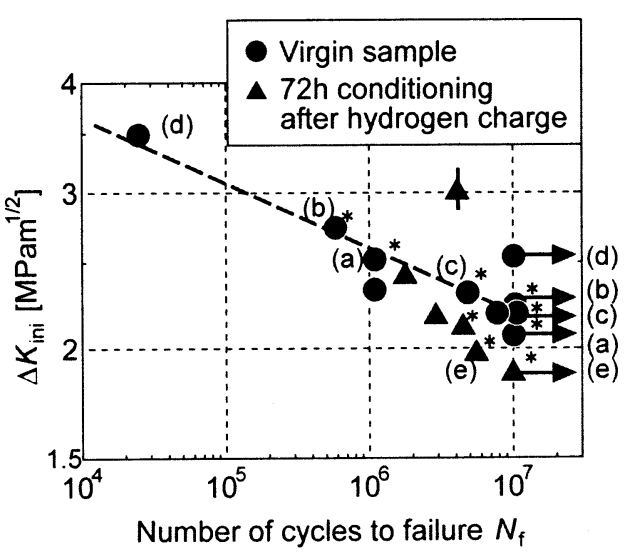

(a) Reduction in area by drawing: $64 \%$

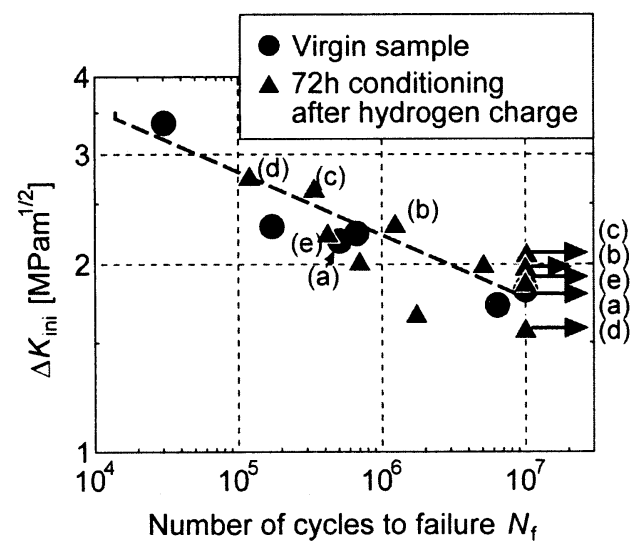

(b) Reduction in area by drawing: $90 \%$

Fig. 4 Influence of irreversible hydrogen on relationship between $\Delta K_{\text {ini }}$ and $N_{\mathrm{f}}$. 
破壊起点の相違が疲労強度特性に及ぼす影響は小 さいものと考えられる。 また，107 cycles を疲労限 と見なして求めた $64 \%$ 材と $90 \%$ 材の未チャージ材 の下限界值を比較すると, 伸線加工により下限界 が低下する傾向にあった.

つぎに，それぞれの供試材における非拡散性水 素の疲労強度に及ぼす影響についてみると，64\% 材では，図 4(a)に示すように，同一の $N_{\mathrm{f}}$ を与える 非拡散性水素吸蔵材の $\Delta K_{\mathrm{ini}}$ は縦線を付したデータ 点を除くと, 未チャージ材に比べて低下している. 特に, $10^{7}$ cycles に近い長寿命域において, 非拡散 性水素吸蔵により疲労強度が低下する傾向にある. なお, 非拡散性水素吸蔵材では組織割れ起点の場 合に疲労強度低下が大きく現れる傾向が見られた. しかし，後述するように，いずれの起点の場合も 末チャージ材とは異なった破面様相を呈していた こと，先に報告 ${ }^{(10)} し た$ 伸線強加工共析鋼において は介在物を起点としていたが，この場合も非拡散 性水素吸蔵による疲労強度低下を生じたことから, 64\%材の場合も起点の種類によらず，非拡散性水 素吸蔵による疲労強度低下が生じるものと考えら れる。

また，図4(a)中の縦線を付した非拡散性水素吸蔵材 のデータ点は, 他の試験片に比べて疲労強度が大きな 值を示している. 本試料の場合を除いて，未チャージ 材, 非拡散性水素吸蔵材いずれの場合も, 起点となっ た介在物あるいは組織割れの欠陷面積は $40 \sim 65 \mu \mathrm{m}^{2}$ で あったのに対して，この場合の起点となった介在物の 大きさは $132 \mu \mathrm{m}^{2}$ と極めて大きいことが他の試料の場 合と異なった．また, 詳細は後述するが, 破面観察の 結果，他の非拡散性水素吸蔵材と同様にぜい性的な破 面様相であったことから，非拡散性水素が疲労破壊に 影響を及ぼしていたものと考えられる.このように破 面様相には非拡散性水素の影響が見られながらも，他 の非拡散性水素吸蔵材に比べて疲労強度が大きくなっ た要因としては, 介在物近傍の残留応力の差異が挙げ られる. すなわち, 介在物寸法が大きい場合は小さい 場合に比べて, 伸線加工により生じる介在物近傍の伸 線方向の圧縮残留応力は FEM 解析によれば大きくな $る^{(18),(19)}$. したがって, 介在物寸法が特に大きい場合は, 介在物に有効に働く応力は小さくなり, その結果, 疲 労強度が大きくなったものと考えられる.

一方, 図 4(b)に示す 90\%材では, 若干ばらつき が見られるが, 非拡散性水素吸蔵材と未チャージ 材はほぼ同一のばらつき帯の中にあり, 両者の疲 労強度特性はほぼ同一であると見なせる.一般に,
材料の降伏応力が高くなるほど水素ぜい化に敏感 になることが知られている．したがって，本研究 で用いた供試材では 90\%材のほうが高強度であり， 水素ぜい化の影響を受けやすいと考えられる。し かしながら，降伏強度が低い64\%材において，非 拡散性水素吸蔵量が小さいにもかかわらず, 疲労 強度が低下した。 それぞれの活性化エネルギーと あわせて考えると, 非拡散性水素のトラップサイ トの活性化エネルギーが小さいほど，非拡散性水 素吸蔵による疲労強度の低下が生じやすくなった ものと考えられる.

$3 \cdot 3$ 疲労破面锶察疲労試験により得た内 部破壊起点近傍の破面を電界放射型走査電子顕微 鏡（FESEM:日立製作所，S-4500）により詳細に観 察した. 図 5,6に64\%材および 90\%材の破面観察 例を示す. 破壊発生起点は，64\%材では，介在物 または図 5(a-1), (b-1)に示すような起点近傍に傾 斜を伴う組織割れの 2 つが観察された.この $2 つ$ の破壊モードは, 水素吸蔵状態に依存せず, 未チ ヤージ材および非拡散性水素吸蔵材の双方で確認 された. EPMAを用いてこの組織割れの成分分析 を行ったが, 母地との相違は見られなかった。ま た, 集束イオンビーム装置を用いて, 破面上の組 織割れの縦断面を FIB 加工により現出し，5\%ナイ タールでエッチングを施した後, 縦断面を SEM で 観察したところ, 周囲の強加工パーライト組織と は異なる微細組織が観察された。このような組織 割れが起点となった疲労破壊は他にも報告(15),(16) されているが, 詳細については明らかになってい ない, 一方，90\%材においては，そのような組織 割れを起点とする場合は見られず，いずれも介在 物が起点であった。

つぎに，非拡散性水素の影響についてみると，64\% 材では, 図5(a-2)で示すように，未チャージ材では微 細な凹凸を有する領域と平坦な領域が混在した破面様 相を呈している. 一方, 図 5(b-2)で示す非拡散性水素 吸蔵材においては, 強加工パーライト組織に依存する, ぜい性的な破面が支配的であり，未チャージ材に比べ て起伏のある破面となっている．90\%材では，破面そ のものは組織に対応した破面様相を呈しているが，末 チャージ材と非拡散性水素吸蔵材の破面の差は見られ ない. 以上の破面様相は, $\Delta K_{\mathrm{ini}}-N_{\mathrm{f}}$ 関係において, $64 \%$ 材では非拡散性水素吸蔵により疲労強度低下が生じ, 90\%材では疲労強度特性に変化が見られなかったこと と対応していると言える. 


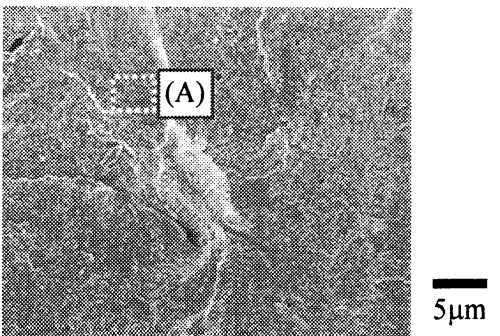

(a-1) FESEM image of crack initiation site.

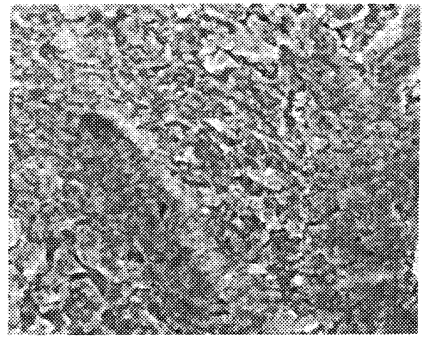

(a-2) Close up image of region (A).
$500 \mathrm{~nm}$

(a) Virgin sample that was subjected to $\Delta \sigma=950 \mathrm{MPa}$, and failed at $4.83 \times 10^{6}$ cycles.

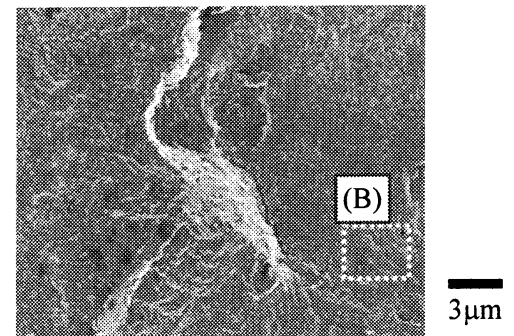

(b-1) FESEM image of crack initiation site.

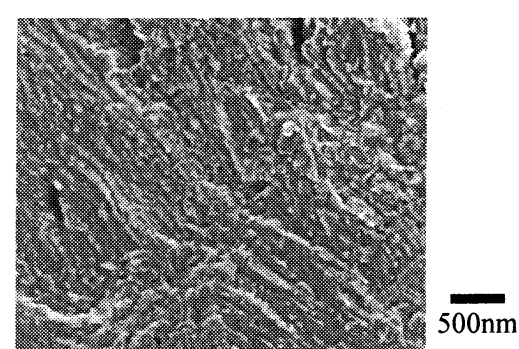

(b-2) Close up image of region (B).

(b) $72 \mathrm{~h}$ conditioning sample in dry air after hydrogen charge that was subjected to $\Delta \sigma=950 \mathrm{MPa}$, and failed at $5.54 \times 10^{6}$ cycles.

Fig. 5 FESEM images of fatigue fracture surfaces near crack initiation site. (Reduction in area by drawing: 64\%)

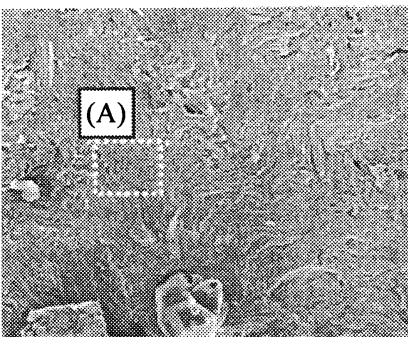

$3 \mu \mathrm{m}$

(a-1) FESEM image of crack initiation site.

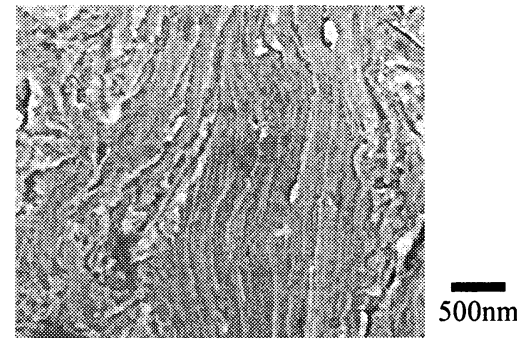

(a-2) Close up image of region (A).

(a) Virgin sample that was first subjected to $\Delta \sigma=1000 \mathrm{MPa}$ for $10^{7} \mathrm{cycles}$. Then the applied stress was increased to $1200 \mathrm{MPa}$, and failed at $5.09 \times 10^{5}$ cycles.

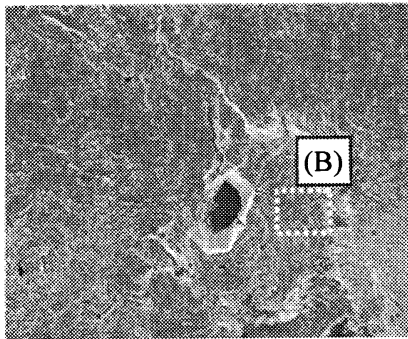

$3 \mu \mathrm{m}$

(b-1) FESEM image of crack initiation site.

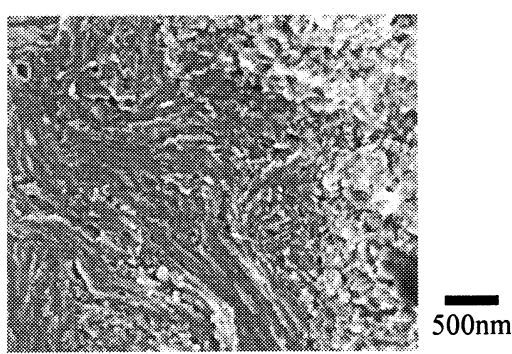

(b-2) Close up image of region (B).

(b) $72 \mathrm{~h}$ conditioning sample in dry air after hydrogen charge that was subjected to $\Delta \sigma=1000 \mathrm{MPa}$, and failed at $1.74 \times 10^{6}$ cycles.

Fig. 6 FESEM images of fatigue fracture surfaces near crack initiation site. (Reduction in area by drawing: $90 \%$ ) 
$3 \cdot 4$ 非拡散性水素吸藏による疲労強度低下と 活性化エネルギーの関連 一定荷重負荷試験の ような静的荷重下および低ひずみ速度引張試験の ような準静的荷重下においては，拡散性水素が水 素ぜい化の主要因子であり, 非拡散性水素は強度 特性に影響を及ぼさないことが知られている(5), (10). これは拡散性水素が室温においても自由に材料内 を拡散するのに対して, 非拡散性水素はトラップ サイトに強くトラップされて拡散できないため, 水素ぜい化には関与しないと考えられている(15). しかしながら, 前報(10)や本研究での 64\%材のよう に，非拡散性水素を吸蔵した条件下においても疲 労強度が低下することが明らかになった。この疲 労強度低下は, 非拡散性水素がトラップサイトか ら脱離し, 応力誘起拡散によりき裂先端へ集積す ることで水素ぜい化を生じたためと考えられる. 繰返し荷重下において, 強くトラップされた非拡 散性水素がトラップサイトから脱離する要因とし ては，繰返し負荷による力学的エネルギーやそれ に伴う熱エネルギ一，き裂先端での転位の駆動な どが考えられる。

先に述べたように，64\%材の場合は非拡散性水素の 影響を受けて疲労強度の低下が生じたのに対して, 90\%材では非拡散性水素の影響が見られないという結 果が得られた. 前述のように, $64 \%$ 材と $90 \%$ 材の非拡 散性水素吸蔵量はそれぞれ $0.84 \mathrm{ppm}, 1.21 \mathrm{ppm}$ であり, 90\%材のほうが多く吸蔵しているにも関わらず非拡散 性水素の影響は小さく，非拡散性水素吸蔵量のみに依 存する現象ではないと考えられる. 非拡散性水素によ る疲労強度低下はトラップサイトからの水素の脱離を 要する現象と考えられることから，脱離の容易さを支 配するトラップサイトの活性化エネルギーが非拡散性 水素の吸蔵条件下における疲労強度特性を支配する重 要な因子の一つと予測される. 3・1節で述べたように, 非拡散性水素の影響が見られなかった $90 \%$ 材の活性化 エネルギーは, 非拡散性水素吸蔵により疲労強度低下 を生じた $64 \%$ 材の活性化エネルギーより約 $11 \mathrm{~kJ} / \mathrm{mol}$ 高 い值を示した．したがって，非抗散性水素のトラップ サイトの活性化エネルギーがより大きい，すなわち， より安定なトラップサイトの場合のほうが非拡散性水 素の影響が現れにくい結果となったものと考えられる. これは，上述したトラップサイトの脱離の機構と関連 しているものと考えられるが, 活性化エネルギ一の影 響も含め, さらに詳細な機構については今後の検討課 題である.
以上のように, 変動応力下において耐水素ぜい化特 性に優れる材料の開発指針としては, 従来の非拡散性 水素トラップサイトの生成に加えて, そのトラップサ イトの活性化エネルギーが重要となり, 活性化エネル ギーのより大きい，水素の安定なトラップサイトがよ り有効であると考えられる.

\section{4. 結言}

非拡散性水素吸蔵による疲労強度低下と非拡散性水 素トラップサイトの活性化エネルギーの関係について 検討するため, 活性化エネルギ一の異なる伸線強加工 高強度鋼を供試材として, 疲労試験を実施した. 得ら れた結果をまとめると以下のようである.

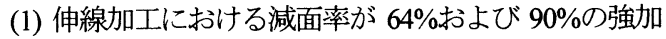
工高強度鋼の拡散性水素のトラップサイトの活性 化エネルギーは，それぞれ $28.7 \mathrm{~kJ} / \mathrm{mol} ， 29.4 \mathrm{~kJ} / \mathrm{mol}$ と求まり, 減面率によらず同程度の值を示した。

(2) 非拡散性水素の場合は, 加工度の増加に伴ってトラ ップサイトの活性化エネルギーは上昇し, 伸線加工 度の上昇とともにトラップサイトは安定化すると 考えられる。

(3) 初期欠陷応力拡大係数範囲 $\Delta K_{\mathrm{ini}}$ を用いて破断寿命 の評価を行った. 非拡散性水素の活性化エネルギー が $60.3 \mathrm{~kJ} / \mathrm{mol}$ の 64\%材では, 非拡散性水素による疲 労強度低下が見られた。一方, 活性化エネルギー $71.4 \mathrm{~kJ} / \mathrm{mol}$ の 90\%材では非拡散性水素吸蔵の前後 で泿労強度特性に変化は見られなかった。

(4) 疲労強度低下が生じた $64 \%$ 材では, 非拡散性水素 を吸蔵することで, 受入れ材に比べて組織に対応し たぜい性的な破面様相に変化した. 一方, 疲労強度 特性に差が見られなかった $90 \%$ 材では，破面様相 にも大きな変化は見られず， $\Delta K_{\mathrm{in}-}-N_{\mathrm{f}}$ 関係と破面様 相には対応関倸が見られた。

(5) 非拡散性水素吸蔵による疲労強度低下には非拡散 性水素トラップサイトの活性化エネルギーが関倸 しており, 活性化エネルギーが高いほど繰返し荷重 下においても耐水素ぜい化特性に優れる結果とな った.

\section{参 考 文 献}

(1) Oriani, R. A. and Josephic, P. H., Testing of the Decohesion Theory of Hydrogen-Induced Crack Propagation, Scripta Metallurgica, Vol. 6 (1972), pp. 681-688.

(2) Birnbaum, H. K. and Sofronis, P., HydrogenEnhanced Localized Plasticity - a Mechanism for Hydrogen-Related Fracture, Materials Science and Engineering A, Vol. 176 (1994), pp. 191-202. 
(3) Tetelman, A. S. and Robertson, W. D., Direct Observation and Analysis of Crack Propagation in Iron-3\% Silicon Single Crystals, Acta Metallurgica, Vol. 11 (1963), pp. 415-426.

(4) Nagumo, M., Ishikawa, T., Endoh, T. and Inoue, Y., Amorphization Associated with Crack Propagation in Hydrogen-Charged Steel, Scripta Metarialia, Vol. 49 (2003), pp. 837-842.

(5) Takai, K. and Watanuki, R., Hydrogen in Trapping States Innocuous to Environmental Degradation of High-Strength Steels, ISIJ International, Vol. 43, No. 4 (2003), pp. 520-526.

(6) Suzuki, S., Ishii, N. and Tsuchida, Y., Diffusible Hydrogen Behavior in Pre-strained High Strength Steel, Journal of the Iron \& Steel Institute of Japan, Vol. 80, No. 11 (1994), pp. 855-859.

(7) Yamasaki, S. and Takahashi, T., Evaluation Method of Delayed Fracture Property of High Strength Steels, Journal of the Iron \& Steel Institute of Japan, Vol. 83, No. 7 (1997), pp. 454-459.

(8) Wei, F. G., Tsuchida, T. and Tsuzaki, K., Hydrogen Trapping in Quenched and Tempered 0.42C-0.30Ti Steel Containing Bimodally Dispersed TiC Particles, ISIJ International, Vol. 43, No. 4 (2003), pp. 539-547.

(9) Tsuchida, T., Hara, T. and Tsuzaki, K., Relationship between Microstructure and Hydrogen Absorption Behavior in a V-bearing High Strength Steel, Journal of the Iron \& Steel Institute of Japan, Vol. 88, No. 11 (2002), pp. 771-778.

(10) Minoshima, K., Nakatani, M., Sugeta, A. and Sakihara, M., Influence of Internal Hydrogen State on the Fatigue Behavior in Cold-Drawn HighStrength Steel, Transactions of the Japan Society of Mechanical Engineers, Series A, Vol. 73, No. 725 (2007), pp.118-124.

(11) Choo, W. Y. and Lee, J. Y., Thermal Analysis of Trapped Hydrogen in Pure Iron, Metallurgical Transactions, Series A, Vol. 13A(1982), pp. 135-140.
(12) Takai, K., Nozue, S. and Kohata, T., Microstructures and Hydrogen Trapping Sites in High-Strength Steels, Current Advances in Materials and Processes, Vol. 15, No. 3 (2002), pp. 1020-1023.

(13) Takai, K., Yamauchi, G., Nakamura, M. and M. Nagumo, Hydrogen Trapping Characteristics of Cold-Drawn Pure Iron and Eutectoid Steel Evaluated by Thermal Desorption Spectrometry, Journal of the Japan Institute of Metals, Vol. 62 No. 3 (1998), pp. 267-275.

(14) Makii, K., Yaguchi, H., Kaiso, M., Ibaraki, N., Miyamoto, Y. and Oki, Y., Influence of Si on Nano Sub-Structure of Cementite Lamellae in Pearlitic Steel Wires, Scripta Materialia, Vol. 37, No. 11 (1997), pp. 1753-1759.

(15) Toriyama, T., Murakami, Y., Yamashita, T. Tsubota, K. and Furumura, K., Inclusion Rating by Statistics of Extreme for Electron Beam Remelted Super Clean Bearing Steel and Its Application to Fatigue Strength Prediction, Journal of the Iron \& Steel Institute of Japan, Vol. 81, No. 10 (1995), pp. 1019-1024.

(16) Abe, T., Furuya, Y. and Matsuoka, S., $10^{10}$-Cycles Fatigue Properties for a Series of SUP7 Spring Steels, Transactions of the Japan Society of Mechanical Engineers, Series A, Vol. 70, No. 696 (2004), pp. 1050-1057.

(17) Murakami, Y. Kodama, S. and Konuma, S., Quantitative Evaluation of Effects of Nonmetallic Inclusions on Fatigue Strength of High Strength Steel, Transactions of the Japan Society of Mechanical Engineers, Series A, Vol. 54, No. 500 (1988), pp. 688-696.

(18) Norasethasopon, S. and Yoshida, K., Finite Element Simulation of Inclusion Size Effects on Copper Shaped-Wire Drawing, Materials Science and Engineering A, Vol. 422 (2006), pp. 252-258.

(19) Nakatani, M and Minoshima, K., unpublished data. 